\title{
Bird Flu: A Birding Threat
}

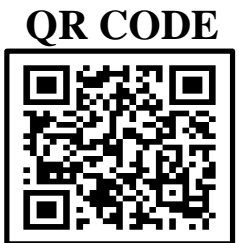

\section{SURABHI DUGGAL ${ }^{(D)}$}

A common viral infection Flu, otherwise known as influenza is one of the infectious diseases prevalent in this season. It spreads easily with its mode of transmission being droplets of cough, cold, or sneeze in the atmosphere, contaminated surfaces such as doorknobs, pillows and blankets, utensils, and much more. A form of communication such as a handshake, kissing, hugging, sharing personal items, sharing drinks as well as food also tends to transmit the infection. ${ }^{1}$

Flu viruses are classified following the 'Centre for Disease Control and Prevention' (CDC) as influenza A, B, C, and D. Every winter the human influenza A virus infects humans. Currently, avian influenza also known as bird flu infects wildlife and human beings. ${ }^{2}$ A majority of the virus forms commonly infects birds when in contact with a carrier.

Bird flu or "avian influenza" is a common viral respiratory disease of domesticated birds along with migratory waterbirds, shipped pet birds, and ostriches which can be directly communicated to humans. 3,4

An outbreak of $\mathrm{H}_{5} \mathrm{~N}_{1}$, the most common form of bird flu appeared in India in 2006 as well as 2021. According to $\mathrm{WHO}$, this strain of bird flu was initially discovered in humans in 1997 leading to the death of $60 \%$ of the human population. It led to severe illness among 18 people of Hong-Kong, of which one-third died. At present, there is no information on the spread of the virus via human contact to a human still specialists are anxious that $\mathrm{H}_{5} \mathrm{~N}_{1}$ may fake a chance of transforming into danger for humans. The World Health Organisation revealed a maximum number of infections and deaths caused by the $\mathrm{H}_{5} \mathrm{~N}_{1}$ virus in Egypt, Indonesia, and Vietnam. The major symptoms include fever, cough, sore throat, nausea, head and muscle aches. Sometimes they may be even worse ranging from conjunctivitis, breathing difficulties, pneumonia, and acute respiratory distress syndrome (ARDS) ${ }^{3}$
Bird flu was seen in the late $1990_{s}$ when a new and highly pathogenic strain originated resulting in the death of millions of birds and poultry. Between 2003 and late 2005 onset of the $\mathrm{H}_{5} \mathrm{~N}_{1}$ strain, a highly mutated one took place amid the poultry in countries like Cambodia, China, Indonesia, Japan, Malaysia, Romania, Russia, South Korea, Thailand, Turkey, and Vietnam. In $2011 \mathrm{H}_{5} \mathrm{~N}_{1}$, a strain of bird flu arose. Furthermore $\mathrm{H}_{7} \mathrm{~N}_{1}$, a new strain appeared in China in the year 2013. Millions of birds died from the disease whereas many were killed in an attempt to control the contagion. Identical coincidental events have been taking place in countries such as Asia, Africa, and the Middle East. ${ }^{4}$

To prevent and control outbreaks of bird flu it is crucial to detect it at an early stage. A mode of detection is polymerase chain reaction (PCR) wherein nucleic acids from blood or tissue samples are analyzed for the presence of molecules specific to bird flu. In addition to PCR, other ways to recognize bird flu are viral antigen detection which discloses the response of antibodies to the viral antigen in samples of skin cells, and viral culture which is used to validate the existence of specific influenza subtypes based on PCR results. Development based on a labon-chip technology that takes minimal time to attain and precisely identifies a subtype of bird flu is going on. A chip with surfaces coated with series of scaleddown laboratory analyses that require only a tiny volume of sample is being developed in this technology. These chip-based tests can be used to detect different subtypes of influenza in both poultry and humans along with being portable and costeffective. ${ }^{4}$

Currently, the virus subtypes that cause influenza in animals are immunologically distinct and also can rapidly evolve into new strains, therefore preparation and discovery of an effective vaccine are complex. A technique to effectively control the outbreaks in poultry as well as reduce human exposure is the removal of infected populations and 
decontamination of farms and types of equipment. Drug manufacturers and policymakers are working towards establishing a vaccine to provide some measure of protection against a future outbreak of bird flu. Studies suggest that antiviral drugs developed for human flu viruses work against bird flu infection in humans. However, the $\mathrm{H}_{5} \mathrm{~N}_{1}$ virus seems to be resistant to drugs such as amantadine and rimantadine. ${ }^{5}$

Wild ducks are the primary hosts for all bird flu subtypes. They carry the virus in their intestines and spread them via feces into the environment. Here they infect domestic birds and the virus passes on to healthy birds through saliva, nasal secretions, and feces. The flu is transmitted at once from farm to farm by airborne feces-contaminated dust and soil, clothing, feed, and equipment, or by wild animals carrying the virus on their bodies within a single region. The disease is spread from region to region by migratory birds and through international trade in live poultry. Humans in close contact with sick birds are at the greatest risk of becoming infected. Viruscontaminated surfaces and intermediate hosts such as pigs can also be sources of infection for humans. ${ }^{6}$

According to IANS (Indo-Asian National Service), seven states of the country have confirmed bird flu. These states are Kerala, Rajasthan, MP, HP, UP, Haryana, and Gujarat. States such as Chhattisgarh, Maharashtra, and Delhi have reported unusual deaths of birds - their reports are awaited. An advisory by the Department of Animal Husbandry and Dairying can be issued to avoid further spread of the disease. ${ }^{7} \mathrm{~A}$ toll-free number has been issued by the department of animal husbandry of Uttarakhand along with a control room to monitor the situation in the state. Six crows were found dead in Dehradun (Uttarakhand) giving rise to a bird flu scare in the region. ${ }^{7}$

Zoological Park in Kanpur has closed its entry for visitors and morning walkers after the death of four fowls and two parrots in the zoo. Samples of dead birds confirmed the presence of $\mathrm{H}_{5}$ strain of bird flu in them. District magistrate of the region has imposed a ban on the transportation of poultry products including live birds and unprocessed poultry meat as a precautionary measure. The ADM of Kanpur has issued advisories involving disinfection of all the farms within one $\mathrm{km}$ of the zoo along with inspection of shops selling raw chicken and mutton. Arrangements have also been made for the disposal of dead birds along with a strict watch on unusual sickness in poultry birds and migratory birds. ${ }^{8}$

\section{REFERENCES}

1. Normandin B. What is bird flu?. (Online Article). Available from: https://www.healthline.com/health/avian-influenza. [Last Accessed on $10^{\text {th }}$ January, 2021] 2. Wikipedia. $2006 \mathrm{H}_{5} \mathrm{~N}_{1}$ outbreak in India. (Online Article). Available from: https://en.wikipedia.org/wiki/2006 $\mathrm{H}_{5} \mathrm{~N}_{1}$ outbreak $\mathrm{i}$ $\underline{n}$ India. [Last Accessed on $10^{\text {th }}$ January, 2021]

3. Sengupta S. Bird Flu: FSSAI Issues 10-Point Guide to Eat Egg And Chicken The Right Way. (Online Article). Available from: https://food.ndtv.com/news/bird-flu-fssai-issues-10point-guide-to-eat-egg-and-chicken-the-right-way2356922. [Last Accessed on $10^{\text {th }}$ January, 2021]

4. CDC. Information on Avian Influenza. (Online Article). Available from: https://www.cdc.gov/flu/avianflu/index.htm. [Last Accessed on $10^{\text {th }}$ January, 2021]

5. Davis CP. Bird Flu (Avian Influenza, Avian Flu). (Online Article). Available from: https://www.medicinenet.com/avian influenza bird flu/article.htm. [Last Accessed on $10^{\text {th }}$ January, 2021] 6. UAB Medicine News. (Online Article). Available from: https://www.uabmedicine.org/news-results/Lasset publisher/CqJrakSPLBWV/content/flu-strainsexplained-and-how-the-vaccine-

works?inheritRedirect=true. [Last Accessed on $10^{\text {th }}$ January, 2021]

7. Times of India. Bird flu: 6 crows found dead, Uttarakhand sets up control room, toll free number. (Online Article). Available from: https://timesofindia.indiatimes.com/city/dehradun/bi rd-flu-6-crows-found-dead-uttarakhand-sets-upcontrol-room-toll-freenumber/articleshow/80150792.cms. [Last Accessed on $10^{\text {th }}$ January, 2021]

8. Times of India. Avian flu scare: Eight zoo birds among 49 culled in Kanpur. (Online Article). Available from: https://timesofindia.indiatimes.com/city/kanpur/avia n-flu-scare-eight-zoo-birdsamong-49-culled-inkanpur/articleshow/80202804.cms. [Last Accessed on $13^{\text {th }}$ January, 2021] 
Cite this article as:

Duggal S. Bird Flu: A Birding Threat. Int Healthc Res J. 2021;4(10):GC1-GC3.

https://doi.org/10.26440/IHRJ/0401.10377

\section{AUTHOR AFFILIATIONS:}

Assistant Professor, Department of Prosthodontics, Crown and Bridge, Sharda University, Greater Noida (ORCID ID: https://orcid.org/oooo-0oo2-9651-5054)

e-mail id for correspondence: surabhi.duggal[at]sharda[dot]ac[dot]in 